\title{
Announcements
}

The Editorial Advisory Board of the Business History Review announces the winner of the 2017 HENRIETTA LARSON ARTICLE AWARD:

Timothy W. Guinnane, Ron Harris, and Naomi R. Lamoreaux "Contractual Freedom and Corporate Governance in Britain in the Late Nineteenth and Early Twentieth Centuries"

A certificate is presented to the authors of the best article published in the volume.

HARVARD BUSINESS SCHOOL BUSINESS HISTORY FELLOWSHIPS.

The Harvard-Newcomen Postdoctoral Fellowship in Business History. To be awarded for twelve months' residence, study, and research at Harvard Business School. The fellowship is open to scholars who, within the last ten years, have received a Ph.D. in history, economics, or a related discipline. The fellowship has two purposes: The first is to enable scholars to engage in research that will benefit from the resources of Harvard Business School and the larger Boston scholarly community. A travel fund and a book fund will be provided. The second is to provide an opportunity for the fellow to participate in the activities of Harvard Business School. Application and related materials are due by October 15, 2018.

Thomas K. McCraw Fellowship. The Thomas K. McCraw Fellowship seeks applicants who are established scholars from around the world interested in the business and economics history of the United States. Recipient receives a \$7,000 stipend for travel and living expenses and is expected to be in residence at Harvard Business School a minimum of two months. Main activities include researching in Baker Library archives or other Boston-area libraries, presenting research at a seminar, and interacting with HBS faculty. Application and related materials are due by October 1, 2018.

The Alfred D. Chandler Jr. International Visiting Scholar in Business History Program. The Alfred D. Chandler Jr. International Visiting

Business History Review 92 (Spring 2018): 149-152. doi:10.1017/Sooo7680518000363 (C) 2018 The President and Fellows of Harvard College. ISSN 0007-6805; 2044-768X (Web). 
Scholar in Business History Program seeks applicants who are established scholars in business history based outside the United States. Recipient receives a $\$ 7000$ stipend and is required to stay a minimum of two months (and not more than six months) at Harvard Business School. Main activities include interacting with faculty and researchers, presenting work at research seminars, and researching in Baker Library archives. Application and related materials are due by October 1, 2018.

The Alfred D. Chandler Jr. Travel Fellowships. The Alfred D. Chandler Jr. Travel Fellowships facilitate library and archival research in business or economic history. Grants range from $\$ 1,000$ to $\$ 3$,ooo. Applicants must be 1) Harvard University graduate students in history, economics, or business administration, research requires travel to distant archives or repositories; 2) graduate students or nontenured faculty in those fields from other Universities-U.S. and abroadresearch requires travel to Baker Library and other local archives; or 3) Harvard College undergraduates writing senior theses in these fields, research requires travel away from Cambridge. Application and related materials are due by November 5, 2018.

Applications can be submitted starting July 1, 2018. For more information and submission instructions, please visit the Business History Fellowships page: http://www.hbs.edu/businesshistory/fellowships/Pages/default.aspx

$$
* * *
$$

\section{HAGLEY MUSEUM AND LIBRARY GRANTS.}

Hagley Exploratory Research Grants. These grants support oneweek visits by scholars who believe that their project will benefit from Hagley research collections, but need the opportunity to explore them on-site to determine if a Henry Belin du Pont research grant application is warranted. Priority will be given to junior scholars with innovative projects that seek to expand on existing scholarship. Applicants should reside more than fifty miles from Hagley, and the stipend is \$400. Application deadlines: March 31, June 30, and October 31.

Henry Belin du Pont Research Grants. These research grants enable scholars to pursue advanced research and study in the collections of the Hagley Library. They are awarded for the length of time needed to make use of Hagley collections for a specific project. The stipends are for a maximum of eight weeks and are prorated at $\$ 400 /$ week for recipients who reside further than fifty miles from Hagley, and $\$ 200 /$ week for those within fifty miles. Application deadlines: March 31, June 30, and October 31. 
Applications for all grants should be submitted via email attachment to Carol Lockman, clockman@Hagley.org. For submission requirements, please visit http://www.hagley.org/research/grants-fellowships. Questions about grant procedures may be directed to Carol Lockman.

BAKER LIBRARY HISTORICAL COLLECTION. Baker Library's “At the Intersection of Science \& Art: Edwin H. Land and the Polaroid Corporation-The Formative Years," features the extensive Polaroid Corporation archives. It can be explored online at https://www.library.hbs.edu/ hc/polaroid/.

For more information about Baker Library Special Collections visit https://www.library.hbs.edu/Find/Collections-Archives/Special -Collections.

BUSINESS HISTORY CONFERENCE MEETING. The 2019 Business History Conference (BHC) will hold its annual meeting in Cartagena, Colombia, from March 14, 2019 to March 16, 2019. The theme is "Globalization and De-Globalization: Shifts of Power and Wealth." Paper proposals are due by October 1, 2018. Please visit the BHC website for more information, http://thebhc.org/call-papers-2019.

WORLD ECONOMIC HISTORY CONGRESS. The next gathering of the World Economic History Congress (WEHC) will convene July 29August 3, 2018 in Boston and Cambridge, Massachusetts to consider the broad theme of "Waves of Globalization." For more information, please visit the conference website at http://wehc2018.org/.

ORGANIZATIONAL HISTORY BLOG. This blog, started by Stephanie Decker, Christina Lubinski, and Dan Wadhwani, aims to be a hub to publish ongoing activities and publications, and exchange ideas and 


\title{
Announcements / 152
}

comments, for those involved in historical approaches to studying organizations. For more information, please visit http://orghist.com/.

COMMODITY HISTORIES. The Commodity Histories website aims to "raise public awareness of the rich histories and cultures of Africa, Asia, the Caribbean and Latin America via their crucial role in the growing of crops and the production of commodities that have become an indispensable aspect of people's daily lives throughout the world" and to that end provides "a public forum for research postings, news and information about the history of commodities." The site also includes a searchable directory of researchers. Produced by the Open University and made possible through funding support from the Arts and Humanities Research Council and the British Academy, the project team members are Sandip Hazareesingh and Mat Paskins. For more information, please visit http://www.commodityhistories.org/.
\end{abstract}

